PAEDAGOGIA ChristianA

2/24 (2009) - ISSN 1505-6872

\title{
Vasil Gluchman, Etika a reflexie morálky, Filozofická fakulta Prešovskej univerzity, Prešov 2008, ss. 282.
}

Prezentowana pozycja wydawnicza z Uniwersytetu Preszowskiego na Słowacji z uwagi na ważkość zawartej w niej doktryny ma istotne znaczenie także dla praktyki edukacyjnej. Dynamicznie rozwijający się ośrodek myśli etycznej i filozoficznej w tej części Europy dopracował się własnej oryginalnej koncepcji etycznej - „etiky sociálnych dôsledkov” zaliczanej do etyki utylitarystycznej. Główną osnową tej myśli są społeczne konsekwencje wyborów podmiotu moralnego. Warto podkreślić, że na bazie tej teorii, obecnej już we wcześniejszych publikacjach, powstają prace mające charakter aplikujący i to także w odniesieniu do etosu zawodowego nauczyciela ${ }^{1}$.

Analizowana książka składa się z dwóch części: 1) etyka społecznych konsekwencji jako teoria słusznego działania i teoria wartości oraz 2) historia etyki na Słowacji w XIX i XX wieku. Z uwagi na ponadlokalny wymiar pierwszej części, tylko ją obejmę swoją refleksją. Cześć pierwsza składa się z sześciu rozdziałów poświęconych następującym zagadnieniom: 1) teorii słusznego działania w etyce społecznych konsekwencji; 2) biologicznym i społecznym czynnikom uwzględnianym w etyce społecznych konsekwencji; 3) idei humanizmu w kontekstach współczesnej etyki; 4) miejscu humanizmu w etyce społecznych konsekwencji; 5) wartości godności ludzkiej w etyce społecznych konsekwencji; 6) prawu moralnemu w jego współczesnych formach refleksji filozoficznej i etycznej. Zawarte w tej monografii rozdziały stanowią podstawy teoretyczne „etiky sociálnych dôsledkov" Vasila Gluchmana. To chyba uzasadnia pragnienie udostępnienia tych przemyśleń polskiemu czytelnikowi.

${ }^{1}$ Zob. M. Gluchmanová, Uplatnenie princípov a hodnôt etiky sociálnych dôsledkov v učitel'skej etike, Filozofická fakulta Prešovskej univerzity, Prešov 2009. 
Kluczowy w systematyzacji tej refleksji jest rozdział pierwszy. Autor ukazuje w nim kryteria oceny ludzkiego działania w kontekście skutków jego czynów. Ostatecznym kryterium wartościowania użyteczności i słuszności ludzkiego działania jest społeczna miara dobra, przewaga pozytywnych skutków nad negatywnymi. Warto wskazać na pewne istotne terminologiczne ujęcia: działania słuszne i niesłuszne, pożyteczne i niepożyteczne; czyny bardzo dobre i niegodziwe (karygodne). Przy czym działanie słuszne może mieć przewagę negatywnych konsekwencji nad pozytywnymi oraz działanie niesłuszne może analogicznie mieć przewagę pozytywnych konsekwencji nad negatywnymi. Podstawowy problem moralny sprowadza się zatem do przewidywania skutków swoich czynów. Stąd rodzi się pytanie nad sposobami rozpoznawania, przewidywania właściwej jakości naszego działania w kontekście konsekwencji. Rozwiązanie tego problemu znajduje się w dalszych rozdziałach.

Rozdział drugi traktuje o biologicznych i społecznych determinantach naszych wyborów. Tutaj autor do rozważań wprowadził pojęcie „mem”. Zasadniczym pytaniem związanym z tym zagadnieniem jest zdolność podmiotu moralnego do obrony przed wpływami „memów”. Ostateczna konstatacja jest taka, że skuteczność obrony zależy od dojrzałości podmiotu moralnego, czyli poniekąd wykształtowania w sobie „typu podmiotu moralnego” (może lepszym określeniem byłoby „osobowości etycznej”). W tym rozdziale etyków „niezorientowanych biologicznie" mogą trochę razić próby procentowego wyliczania wpływów społecznych i biologicznych.

Rozdział trzeci stanowi wprowadzenie przez autora do własnych przemyśleń zagadnienia roli idei humanizmu w koncepcji etycznej. Kontynuacją tych przemyśleń jest rozdział czwarty. Odpowiedzią jest ogólne założenie powiązania w „etyce społecznych konsekwencji” godności ludzkiej, praw moralnych i humanizmu z sumą pozytywnych konsekwencji ludzkich działań w wymiarze społecznym.

Temu zadaniu przyświecają także dwa kolejne rozdziały. Godność człowieka, pomimo pewnie zastrzeżeń personalistów, stanowi ważne ogniwo w ,etyce społecznych konsekwencji" przynależnej do nurtu neoutylitarystycznego konsekwencjonalizmu. Ta zbieżność idei „pozytywnych społecznych konsekwencji” jako podstawowego kryterium wartościowania z godnością człowieka dokonuje się na gruncie sumy dobra społecznego. Decydują o tym dwa elementy: uznanie dla życia, a więc także otoczenie szacunkiem osoby ludzkiej, oraz pozytywnokreatywna rola zabezpieczenia ludzkiej godności w osiaganiu przewagi pozytywnych skutków.

Podsumowaniem refleksji w teorii „etiky sociálnych dôsledkov” jest zagadnienie prawa moralnego. Za jego podstawę Vasil Gluchman uznaje prawo do życia, przy czym rozciaga je na istoty świadome i nieświadome tegoż prawa. Idea humanizmu i godność człowieka opierają się na prawie do życia. Prawo moralne swą obowiązującą moc czerpie zatem z uznania dla życia, jako centralnej wartości społecznej. Z niego też wynikają prawa socjalne i obowiązek wspierania osób ludzkich w rozwoju. 
Z uwagi na praktyczny rozwój teorii utylitarystycznych, polecam lekturę Etika a reflexie morálky Vasila Gluchmana polskim czytelnikom. Jest to dzieło twórcze, w którym zostały zawarte autorskie koncepcje „etiky sociálnych dôsledkov”. Publikacja ta wpisuje się w nurt „neoutylitarystycznego konsekwencjonalizmu” stosunkowo słabo obecny w polskiej myśli etycznej. Na pewno ta koncepcja pozostaje w opozycji do myśli etycznej wyrosłej z moralności chrześcijańskiej. Niemniej jednak istnieje stała konieczność konfrontacji uzasadniania działań etycznych, zwłaszcza gdy akceptuje się wspólne wartości, a za taką należy bez wątpienia uznać godność osoby ludzkiej.

Grzegorz Grzybek

Witold Starnawski, Prawda jako zasada wychowania. Podstawy pedagogii personalistycznej w nawiqzaniu do myśli Karola Wojtyly - Jana Pawła II, Wydawnictwo Uniwersytetu Kardynała Stefana Wyszyńskiego, Warszawa 2008, ss. 580.

Podejmowanie refleksji filozoficznej nad otaczającą człowieka rzeczywistością ma na celu coraz bardziej precyzyjne, głębokie rozumienie owej rzeczywistości. Jednym z najważniejszych dzieł, realizowanych przez człowieka, jest dzieło wychowania. Filozoficzny ogląd działalności wychowawczej jest obecnie $\mathrm{z}$ jednej strony zepchnięty na margines zainteresowań pedagogicznych, a z drugiej zaś niezwykle potrzebny. Specjalizacja w różnych dziedzinach wychowania i konieczność poświęcenia coraz większej ilości czasu na przyswojenie sobie nowoczesnych metod i technik pracy z wychowankiem sprawiają bowiem, że ogólna refleksja nad wychowaniem jest coraz bardziej ograniczana. Równocześnie wielu pedagogów zdaje się budować swój model świata i procesu wychowania oraz wartościować poszczególne jego elementy, opierając się na funkcjonujących w kulturze, bardzo często uproszczonych stereotypach myślowych. W tym kontekście praca Witolda Starnawskiego na temat zależności między prawdą i wychowaniem jawi się jako niezwykle cenny materiał do przemyśleń zarówno dla teoretyków wychowania, jak i dla praktyków, pracujących na co dzień z dziećmi i młodzieżą. Należy ponadto dodać, że jest to temat trudny i kontrowersyjny. W kulturze przełomu XX i XXI wieku, kształtowanej pod znacznym wpływem nurtów myślowych, obejmowanych określeniem „postmodernistyczne”, termin „prawda” stał się synonimem poglądu, czyli stracił swój obiektywny charakter na

* Dr hab. Grzegorz Grzybek, prof. UR, zatrudniony w Instytucie Pedagogiki Uniwersytetu Rzeszowskiego, Katedra Pedagogiki Medialnej i Komunikacji Społecznej, oraz w Wyższej Szkole Filozoficzno-Pedagogicznej „Ignatianum” w Krakowie, Katedra Nauk o Rodzinie. 